\title{
Residential archetypes in urban energy simulation models in Chile: Determining factors of residential energy consumption
}

\section{Arquetipos residenciales en los modelos de simulación energética urbana en Chile: Factores determinantes del consumo energético residencial}

Francisca Aguilera (Main Author)

Escuela de Construcción Civil, Facultad de Ingeniería

Pontificia Universidad Católica de Chile

Vicuña Mackenna 4860, Macul, Santiago (Chile)

fnaguilera@uc.cl

Felipe Ossio (Corresponding Author)

Escuela de Construcción Civil, Facultad de Ingeniería

Pontificia Universidad Católica de Chile

Vicuña Mackenna 4860, Macul, Santiago (Chile)

faossio@uc.cl

Manuscript Code: 954

Date of Acceptance/Reception: 13.12.2017/03.08.2017

DOI: 10.7764/RDLC.16.3.527

\section{Abstract}

The national and international overview has shown that residential energy consumption is increasing. As a result, efforts have focused on reducing the initial demand for housing and its associated consumption. One of the most used tools for this purpose is bottom-up energy modelling, specifically on the archetypes branch. This method proposes that energy demand of a dwelling can estimated from the interaction of several parameters and factors. However, the method's main limitation, is the complexity of defining the variables and factors to be used. This article presents a review of specialized literature, concerned with, determining and characterizing residential archetypes. From this literature, It was possible to determine the most influential factors in energy consumption. The results showed 19 factors that were categorized into five groups; general, geometric, thermal, operational, and systems and equipment characteristics. The applicability of these factors to Chile was verified. This article, is intended a guide to generating representative archetypes and characterizing dwellings in an efficiente manner.

Key words: energy efficiency, bottom-up modelling, archetypes, residential energy consumption, urban energy simulation.

\section{Resumen}

El panorama nacional e internacional han demostrado que el consumo energético residencial está en alza. Por lo cual, los esfuerzos se han centrado en disminuir la demanda inicial de las viviendas y su consumo asociado. Para esto, una de las herramientas más utilizadas corresponde metodología bottom-up, específicamente del tipo arquetipos. Esta propone, que, a través de la interacción de diversos parámetros y factores, se puede obtener demanda energética de una vivienda, generando así arquetipos representativos del stock de viviendas simuladas, el cual se puede extrapolar a distintos niveles. Sin embargo, la principal limitante, corresponde a la complejidad de definir las variables y factores a utilizar. Este artículo presenta una revisión de literatura especializada, donde se compilaron las variables, más utilizadas en el consumo energético, para determinar y caracterizar arquetipos residenciales. Se obtuvieron 19 variables las que se categorizaron en cinco niveles; características generales, geométricas, térmicas y operacionales, y de equipamiento y sistemaas, a las que, se les verificó su aplicabilidad en Chile. A través de este artículo se pretende generar una guía que permita realizar una caracterización eficiente de las viviendas y su contextualización, de manera que los arquetipos que se puedan generar sean lo más representativos posibles.

Palabras Claves: eficiencia energética, modelación bottom-up, arquetipos, consumo energético residencial, simulación energética urbana.

\section{Introduction and Problem Description}

During the last few years there has been a sustained increase in world energy consumption. According to studies results, the European Union projects that during the 2000-2030 period energy demand will increase at a rate of $1.8 \%$ per year (Montes \& Moreno, 2016). This directly impacts the environment through: the destruction of the ozone layer, the increase in greenhouse gas emissions (GHG), global warming and consequent climate change, among others (PérezLombard, Ortiz, \& Pout, 2008).

According to the United Nations (UN), the construction sector is responsible for $40 \%$ of the total energy used and the global GHG emissions (Dyrbol, Thomsen \& Alnaek, 2010). Regarding to Chile, according to the National Energy Commission the commercial, public, and residential sector consume $26 \%$ of the energy produced at the country level. The residential sector represents $79 \%$ of that total (Ministerio de Energía Gobierno de Chile, 2017). 
The adoption of design criteria based on the improvement of energy efficiency of housing has shown be a viable strategy to reduce the initial demand, and the consumption of the users (Pacheco, 2014). To apply these types of measures, it is necessary to know the composition of energy demand in the residential sector.

One of the forms used to determine residential energy consumption is the bottom-up method. This method allows model energy demand of a house, then generate representative archetypes of the stock of simulated dwellings, which can be extrapolated to different levels. Although it is a widely used methodology at the international level (AydinalpKoksal \& Ugursal, 2008; Swan \& Ugursal, 2009; Yao \& Steemers, 2005), this method requires information about parameters and factors that are not always available (Famuyibo, Duffy, \& Strachan, 2012).

Although in Chile, the residential sector has been a source of different types of research: Guías de Diseño (Blanco, Martínez, \& Jarpa, 2003; Bustamante, Cepeda, Marínez, \& Santa María, 2010; D'Alençon, Justiniano, Márquez, \& Valderrama, 2008; Castillo, Universidad de Chile, Universidad Técnica Federico Santa Maria \& Fundación Chile, 2004; Müller, 2002); Estudios (Bustamante et al., 2010; Martínez, 2006; Sarmiento \& Hormazábal, 2003); Recomendaciones de Ley (Ambiente Consultores et PRIEN, 2007); among others, there is still no certainty about which parameters are considered essential for a successful energy simulation based on the bottom-up method.

Ossio (2015) shows that the context (regulatory, cultural, characteristics of the industry, among others) has a strong impact on the energy performance of a house and consequently its simulation must consider the particularities of that context. The existing housing stock in Chile that grows at a rate of approximately 150,000 homes per year (Instituto Nacional de Estadísticas, 2010) differs strongly according to its geographical location. In the same way, climatic variability, which in Chile reaches 17 climatic zones according to the Koppen-Geiger classification, strongly influences the energy performance of these properties. Therefore, it is essential to focus efforts on generating information that allows the determination of residential archetypes appropriate to the Chilean context and its future modeling (Sokol, 2015).

Due to this, the following article aims to review the state of national and international art to identify, process and conclude, regarding the extent of use of different determinant factors in residential energy consumption, used at urban level, in this kind of modeling. Through a meta-analysis, it will be intended to review specialized literature, like congressional proceedings, international and indexed journals, databases and specialized books on the subject to be studied.

State of the Art

According to Rojo (2016) existing residential models can be classified based on two large groups,

1. Those that are related to the detail level of the inputs

2. Those models that are cataloged according to the way they evaluate residential energy consumption.

The top-down models are based on the relationship between the energy sector and the economy of a region or country, and that is why their collection of information is done with respect to historical data (Kavgic et al., 2010). They start from a global structure, where relations are ordered and fixed among all the constituent elements (Rojo, 2016). The top-down models estimate the energy consumption based on macroeconomic indicators, relevant at the national or regional level (Muratori, Roberts, Sioshansi, Marano, \& Rizzoni, 2013). However, one of the limitations of this type of approach is the difficulty of knowing in detail the final uses of residential energy (Kavgic et al., 2010).

On the other hand, bottom-up models seek to estimate energy consumption through the characteristics of a group of dwellings, thus extrapolating the results at different levels. Within this category, an engineering approach of the archetype class can be used too, which through a classification of existing buildings seeks to develop representative archetypes for existing housing stock, it provides different inputs for the simulation models energy (Swan \& Ugursal, 2009). One of the advantages of this model is the possibility to simulate the effect of different technologies on the total energy consumption (Dineen \& Ó Gallachóir, 2011). However, Muratori et al. (2013), says that it is an appropriate tool to evaluate political decisions in the sustainability area.

Archetypes is one of the most used techniques to categorize the housing stock and describe the residential energy consumption. The inputs that are commonly considered to classify an archetype are: function of the building, area, plant geometry, age, among others. They are characterized according to the factors that affect energy consumption, such as building envelope, ventilation, air conditioning, operating characteristics and internal loads (Sokol, Cerezo Davila, \& 
Reinhart, 2017). It should be noted that having a greater amount of reliable information results in more trustworthy results (Swan \& Ugursal, 2009).

So far, the review of the literature related to the subject has been in the hands of Reinhart, \& Cerezo Davila (2016), who have portrayed the different models of simulation and approximations. Although they deal with the organization of the inputs in the bottom-up models, they only indicate which parameters are normally used, so they leave a non-study area to continue with a deeper investigation linked to the importance of the correct choice of inputs.

In Japan, residential archetypes were determined to simulate energy consumption at the country level. In this study, the family distribution and type of housing were considered as variables, as well as other factors related to the use of housing, climatic characteristics, among others. Along with the above, it was pointed out that through these types of tools, the results of actual energy policies can be evaluated, as well as modify the scenarios, internal loads and varying occupancy parameters, in order to predict the future energy changes (Shimoda, Fujii, Morikawa, \& Mizuno, 2004).

In the case of the United Kingdom, there is multiple research on the determination of archetypes. Most agree that through these there can be generated design guides for each type of housing since this could have clear information regarding the energy consumption and carbon emissions of the residential sector of the stock of existing housing (Karolija, Marjanovic-Halburd, Zhang, \& Hanby, 2013; Marshall, Steinberger, Dupont, \& Foxon, 2016; Yao \& Steemers, 2005).

Regarding the representativeness of the results, in Ireland the methodology was applied, to determinate 13 residential archetypes which represent $65 \%$ of dwellings in the housing stock. Although this percentage was considered representative for this particular case, the result could be more favorable in case of having even more updated and reliable databases (Famuyibo et al., 2012).

An innovation in the subject was carried out in the United States, where they worked under the ResStock method, which represents a greater amount of housing stock and climate characteristics throughout the country, which makes it a methodology of high detail. This allows a large number of representative buildings to be considered appropriate, due to the number of possible combinations of general building characteristics (e.g., location, vintage, size, number of stories, foundation type, and heating fuel type) and detailed building component characteristics (e.g., insulation levels, equipment efficiencies) (Wilson, Christensen, Horowitz, \& Horsey, 2016). This indicates that the required level of detail depends on the level of confidence needed by the analysis.

On the other hand, Chile created the Housing Energy Qualification System (HEQ), a tool that provides information about the energy efficiency in dwellings. The system considers parameters related to heating, lighting and domestic hot water. It allows to estimate demands and energy consumption of houses, for which it considers factors such as: thermal insulation, use of thermopanel glass, orientation of housing and energy sources. By means of this the homes are described according to letters, which indicate whether or not it meets the minimum requirements established by the thermal regulation and what is the energy savings associated with this type of housing (MINVU, 2013). While this can be considered as an advance in the topic of energy simulation, they do not qualify as residential archetypes.

This article will be a first approach to residential energy modeling through a systematic review of the literature associated with the bottom-up method and archetypes. It will allow to know, which are the factors and parameters most used to determine archetypes at urban level.

Methodology

The bibliographic research was made under the method of a quantitative systematic review, also known as metaanalysis. All the information recollected will be organized according to a punctual estimator (Girao, Olmedo, \& Ferrer, 2008). Which is also the same method proposed by Aldana \& Serpell (2012) for different literature reviews.

The literature review was carried out using databases such as ScienceDirect (Elsevier), Springer, Google Scholar, and the library of the Pontificia Universidad Católica de Chile. The most frequently used keywords were "bottom-up model", "residential sector", "stock modeling", "residential end-use energy", "residential building stock", "building archetype", "energy simulation", "domestic energy", "building energy demand", "household energy consumption", "stock aggregation", among others. In order to reduce the results obtained. For example, in the case of the ScienceDirect database, it was filtered by categories, such as "Energy", "Engineering", "Environmental Science", etc. This procedure was replicated in all databases examined. 
All the articles that are not in the context of energy consumption were discarded. Finally, 100 articles published between 1998 and 2017 were selected. The above information is summarized in Table 1.

\begin{tabular}{lc} 
Table 1. Number of Articles reviewed per journal on the topic of residential energy modeling. \\
\cline { 1 - 2 } Journal's name & No of articles \\
\hline Applied Energy & 3 \\
Building Simulation & 1 \\
Building and Environment & 5 \\
Building Industry Trends & 1 \\
Cleaner Production & 2 \\
Energy & 3 \\
Energy and Buildings & 36 \\
Energy Efficiency & 4 \\
Energy for sustainable Development & 1 \\
Energy Policy & 3 \\
Energy Procedia & 3 \\
Energy, Sustainability and Society & 1 \\
Renewable and Sustainable Energy & 5 \\
Reviews & \\
Sustainable Cities and Society & 2 \\
Visualization in Engineering & 1 \\
Urban Climate & 1 \\
Journal of Industry Ecology & 1 \\
Others & 27 \\
Total & 100 \\
\hline
\end{tabular}

The selection of articles was analyzed considering urban energy simulation as a central theme. Thus it's necessary to specify that all the articles must contain a bottom-up modelling for residential dwellings and also need to define residential archetypes. Consequently, all the articles that were not within the focus of the study were removed. The results were compiled in Table 2 .

\begin{tabular}{|c|c|c|}
\hline Journal & References & No of Articles \\
\hline Energy and Buildings & $\begin{array}{l}\text { (Pérez-Lombard et al., 2008; Yao \& Steemers, } \\
\text { 2005; Famuyibo et al., 2012; Sokol et al., 2017; } \\
\text { Jermyn \& Richman, 2016; Kavgic, Mumovic, } \\
\text { Summerfield, Stevanovic, \& Ecim-Djuric, 2013; } \\
\text { Ghiassi \& Mahdavi, 2017; Österbring et al., 2016) }\end{array}$ & 8 \\
\hline Building Simulation & (Jones, Lannon, \& Williams, 2001) & 1 \\
\hline Building Industries Trends & (Huang \& Brodrick, 2000) & 1 \\
\hline Renewable and Sustainable & $\begin{array}{l}\text { (Swan \& Ugursal, 2009; Hereen, Jakob, Martius, } \\
\text { Gross, \& Walbaum, 2013) }\end{array}$ & 2 \\
\hline Building and Environment & $\begin{array}{l}\text { (Shimoda et al., 2004; Kavgic et al., } \\
\text { 2010;Mavrogianni, Wilkinson, Davies, Biddulph, } \\
\text { \& Oikonomou, 2012; Booth, Choudhary, \& } \\
\text { Spiegelhalter, 2012) }\end{array}$ & 4 \\
\hline Energy Procedia & $\begin{array}{l}\text { (Monteiro, Pina, Cerezo, Reinhart, \& Ferrao, } \\
\text { 2017; Pittam, O'Sullivan, \& O'Sullivan, 2014; } \\
\text { Mutani, Delmastro, Gargiulo, \& Corgnati, 2016 ) }\end{array}$ & 3 \\
\hline Sustainable Cities and Society & $\begin{array}{l}\text { (Muringathuparambil, Musango, Brent, \& Currie, } \\
\text { 2017) }\end{array}$ & 1 \\
\hline Urban Climate & $\begin{array}{l}\text { (Tornay, Schoetter, Bonhomme, Faraut, \& } \\
\text { Masson, 2017) }\end{array}$ & 1 \\
\hline Others & $\begin{array}{l}\text { (Arababadi, 2012;Martinsson, Krook-Riekkola, } \\
\text { Lindblom, \& Wrake, 2014; Cerezo, Sokol, } \\
\text { Reinhart, Al-Mumin, 2015; Sokol, 2015; Dineen, } \\
\text { 2014; Mitchell, 2005; Raslan \& Mavrogianni, } \\
\text { 2013; García-Pérez, Sierra-Pérez, Boschmonart- } \\
\text { Rives, Lladó Morales, \& Romero Calix, 2017; Li, } \\
\text { 2014; Ribas, 2012; Medina, 2011; Österbring, } \\
\text { 2016; Pacheco, 2014; Wilson, Christensen, } \\
\text { Horowitz, \& Horsey, 2016) }\end{array}$ & 14 \\
\hline Total & & 36 \\
\hline
\end{tabular}


Each publication was studied to identify the categories and factors that define archetypes in energy simulation models. According to Ghiassi \& Mahdavi (2017) and Wilson, Christensen, Horowitz \& Horsey (2016) the factors can be classified in five categories:

1. General information

2. Geometric characteristics

3. Thermal characteristics of the envelope

4. Systems and equipment

5. Operational characteristics

Table 3 shows the 33 factors obtained and their categorization.

\begin{tabular}{|c|c|}
\hline Category & Factor \\
\hline \multirow[t]{4}{*}{ General information } & Year of construction \\
\hline & $\begin{array}{l}\text { Type (i.e. detached, semidetached house, among } \\
\text { others) }\end{array}$ \\
\hline & Geographic location (i.e. urban, rural) \\
\hline & Climatic Zone \\
\hline \multirow[t]{15}{*}{ Geometric characteristics } & Floor area \\
\hline & Heating floor area \\
\hline & Cooling floor area \\
\hline & Floor area of the bigger story \\
\hline & Exposed end area \\
\hline & Facade area \\
\hline & Shape \\
\hline & Number of stories \\
\hline & Number of chimney pot \\
\hline & Window area \\
\hline & Storey height \\
\hline & Window/Wall ratio \\
\hline & Wall/Floor ratio \\
\hline & Volume \\
\hline & Orientation \\
\hline \multirow[t]{7}{*}{ Thermal characteristics } & Envelope \\
\hline & Ventilation system \\
\hline & Infiltration \\
\hline & Glazing type \\
\hline & Conductivity \\
\hline & Internal temperature \\
\hline & Insulation level \\
\hline \multirow{5}{*}{$\begin{array}{l}\text { System and equipment } \\
\text { characteristics }\end{array}$} & Cooling system \\
\hline & Heating system \\
\hline & Domestic hot water (DHW) \\
\hline & Fuel \\
\hline & Occupancy level \\
\hline \multirow{2}{*}{$\begin{array}{l}\text { Operational } \\
\text { characteristics }\end{array}$} & Lighting and equipment \\
\hline & Household income \\
\hline
\end{tabular}

All the factors were compiled in a matrix, and then it was identified how frequently each of the factors and variables were used, as percentage of studies. 
Certain factors were used universally in literature (100\%) such as the geographic location. However there were less frequent variables, such as the number of chimney pots, which only reaches $2.6 \%$. This information is summarized in Table 4.

\begin{tabular}{|c|c|c|}
\hline Category & Factor & Percentage \\
\hline \multirow{4}{*}{$\begin{array}{l}\text { General } \\
\text { information }\end{array}$} & Year of Construction* & 89.7 \\
\hline & $\begin{array}{l}\text { Type (i.e. detached, semidetached } \\
\text { house, among others)* }\end{array}$ & 94.9 \\
\hline & $\begin{array}{l}\text { Geographic location (i.e. urban, } \\
\text { rural)* }\end{array}$ & 100.0 \\
\hline & Climate Zone* & 43.6 \\
\hline \multirow{15}{*}{$\begin{array}{l}\text { Geometric } \\
\text { characteristics }\end{array}$} & Floor area* & 94.9 \\
\hline & Heating floor area & 64.1 \\
\hline & Cooling floor area & 12.8 \\
\hline & Floor area of the bigger story & 7.7 \\
\hline & Exposed end area & 12.82 \\
\hline & Facade area* & 53.9 \\
\hline & Shape* & 48.7 \\
\hline & Number of stories* & 41.0 \\
\hline & Number of chimney pot & 2.6 \\
\hline & Window area* & 64.1 \\
\hline & Storey height* & 41.0 \\
\hline & Window/Wall ratio & 35.9 \\
\hline & Wall/Floor ratio & 5.1 \\
\hline & Volume & 10.3 \\
\hline & Orientation* & 31.6 \\
\hline \multirow{7}{*}{$\begin{array}{l}\text { Thermal } \\
\text { characteristics }\end{array}$} & Envelope & 97.4 \\
\hline & Ventilation system & 53.9 \\
\hline & Infiltration & 35.9 \\
\hline & Glazing type & 35.9 \\
\hline & Conductivity & 18.0 \\
\hline & Internal temperature* & 82.1 \\
\hline & Insulation level & 41.0 \\
\hline \multirow{4}{*}{$\begin{array}{l}\text { System and } \\
\text { equipment } \\
\text { characteristics }\end{array}$} & Cooling system & 66.7 \\
\hline & Heating system* & 66.7 \\
\hline & Domestic hot water (DHW)* & 56.4 \\
\hline & Fuel* & 56.4 \\
\hline \multirow{3}{*}{$\begin{array}{l}\text { Operational } \\
\text { characteristics }\end{array}$} & Occupancy level* & 79.5 \\
\hline & Lighting and equipment* & 89.7 \\
\hline & Household income* & 25.6 \\
\hline
\end{tabular}

It is necessary to verify the duplication of parameters and factors. An it's also important to corroborate if the factors can be applied to the Chilean reality. In this case it was concluded that:

- The factors floor area, heating floor area, cooling floor area, floor area of the bigger storey, can be simplify to floor area. As indicated by Ghiassi and Mahdavi (2017), these parameters can have different results in houses that have attics (non-heating / cooling zone). However, the Chilean dwellings don't have this type of living space inside.

- The factors exposed end area and orientation have a similar meaning, According to Pacheco (2014), both factors make reference to the exposition to solar radiation.

- The factors ventilation system and cooling system are not applicable to the Chilean reality, because most homes in the country use natural ventilation. Both variables are discarded.

- Materiality, conductivity and insulation factors describe characteristics of the envelope material, so it is only necessary to maintain the materiality factor.

All factors with a frequency of use greater than or equal to $40 \%$ are considered representative, it will be necessary to make an exception for the variable household income. Thus, 19 factors are obtained, which are marked with an asterisk in Table 4. 
The household income, belonging to the operational characteristics category, has a frequency of use of $25.6 \%$. The low utilization of this factor in the determination of archetypes can be associated with its recent origin, according to the international literature. However, the household income is a factor that delivers important information, it brings a socio - economic component, it has to do with the users behavior house, which provides a more accurate characterization regarding the different types of users (Madeira \& Haunstrup, 2016).

The parameters type and the year of construction of the dwellings can be considered very useful, because it quickly provides information about the construction practices, materialities and characteristics of the building (Sokol, 2015). The year of construction also provides information on changes in regulations made during the given period, which allows to observe an overview before and after in the energy consumptions. This would be very useful in the Chilean case, since in 2008 the change to the thermal regulation was approved, which was reflected in the update of the NCh1079 (Instituto Nacional de Normalización, 2008)

The factors floor area, facade area, shape, number of stories, window area, storey height and orientation were grouped into the category of geometric characteristics, which characterizes the building to be studied (Aksoenzen, Daniel \& Kolher, 2014).

In the case of building shape, it considers the influence of the solar radiation, which is why it acts as a determinant in the energy requirements of the user regarding the levels of use of heating systems, hours of use of luminaires, between others (Mingfang, 2002). Elasfourl, Maraqa \& Tabbalat (1991) mention that a housing with a favorable shape could reduce its energy requirements by up to $25 \%$. If adequate guidance is considered, it is indicated that heating savings could reach even $36 \%$ (Aksoy \& Allani, 2006).

On the other hand, regarding the thermal characteristics, materiality of the envelope of the building influences the level of use of heating systems, and therefore, has a great influence in the energy consumption of the building (Manioglu \& Yilmaz, 2006). The tightness determines the indoor climate conditions, ie the interior temperature of the dwellings and ventilation levels, which directly interact with the use levels of heating systems used to maintain comfort in a dwelling.

The operational characteristics are related to the use of the dwelling, ie, the number of occupants and their use patterns, which shows the hours with greater use of lighting, appliances and hot water. In this way, it reflects the preferences of the occupants and how they develop their activities inside the dwelling. These depend clearly on the comfort level that the user intends to reach (Sokol, 2015).

The high energy consumption of the construction sector is considered an important issue at the national and international level. Because of this, research efforts have been focused on generating solutions to reduce the initial demand for housing and its associated consumption.

The archetypes method has been used to predict energy changes, scenario modifications, among other things. It proposes that, through the interaction of various parameters and factors, energy demand can be obtained from a dwelling, thus generating archetypes representative of the simulated housing stock, which can be extrapolated to different levels.

However, one of the difficulties associated with the determination of archetypes has to do with the complexity of defining the parameters and factors to be used. Therefore, through this study, a systematic review of specialized literature was conducted, in order to classify the most used variables, and to verify their applicability in Chile.

According to the above, 19 factors were defined, which are considered determinants in the urban residential energy consumption, and are summarized below:

- General information: year of construction, type of dwelling, location and climatic zone.

- Geometric characteristics: floor area, facade area, shape, number of floors, window area, story high y orientation.

- Thermal characteristics of the envelope: materiality of the envelope and internal temperature.

- Systems and equipment: heating system, hot water and associated fuels.

- Operational characteristics: occupation pattern, lighting and equipment, and household income.

It should be noted that the category of operational characteristics which, although not observed in most of the bibliography consulted, does play an important role in accurately characterizing user behavior and its influence on the energy consumption of housing. 
Through this selection of variables, the aim is to characterize and contextualize the housing stock, so that the archetypes generated are as representative as possible. This review also could guide future research in order to the prioritization of national research efforts, strengthening the databases available. In this manner, it may be able to constraint the uncertainly and achieve even more accurate and representative energy simulations. In the long term, they will serve as the basic information for the assurance of constant electricity supply.

Regarding the implications, it is expected that the results obtained through the bibliographic review, become useful information for the private sector, so that it serves as a guide when selecting the factors necessary to perform a dynamic simulation. On the other hand, for the public sector, it is expected to be a reference guide that allows to be a knowledge base when it comes to generating regulations or updating them.

Acknowledgements

The authors wish to thank the sustainable urban research group, GIUS of the Pontificia Universidad Católica de Chile, for their contributions and revisions. They also thank to Constanza Molina, Claudia Rojo, Ximena Ferrada, for their revisions. The comments of reviewers greatly improved the quality of this work.

Aksoezen, M., Daniel, M., Hassler, U., \& Kohler, N. (2015). Building age as an indicator for energy consumption. Energy \& Buildings, 87, 74-86. http://doi.org/10.1016/j.enbuild.2014.10.074

Aksoy, U., \& Inalli, M. (2006). Impacts of some buildings passive design parameters on heating demand for a cold region. Building and Enviroment, $41(12), 1742-1745$.

Aldana, J., \& Serpell, A. (2012). Temas y tendencias sobre residuos de construcción y demolición: Un metaanálisis. Revista de la Construcción, 11(2), 4-16. https://doi.org/10.4067/S0718-915X2012000200002

Arababadi, R. (2012). Energy use in the UE building stock case study: UK. MSc Thesis, Linköping, University. Linköping, Sweden.

Aydinalp-Koksal, M., \& Ugursal, V. I. (2008). Comparison of neural network, conditional demand analysis, and engineering approaches for modeling end-use energy consumption in the residential sector. Applied Energy, 85(4), 271-296. https://doi.org/10.1016/j.apenergy.2006.09.012

Blanco, T., Martínez, J., \& Jarpa, G. (2003). Análisis e incorporación de factores de calidad habitacional en el diseño de las viviendas sociales en Chile. Propuesta metodológica para un enfoque integral de la calidad residencial. Revista INVI, 18(46),9-21.

Braulio-Gonzalo, M., Bovea, M. D., Ruá, M. J., \& Juan, P. (2016). A methodology for predicting the energy performance and indoor thermal comfort of residential stocks on the neighborhood and city scales. A case study in Spain. Journal of Cleaner Production, 139 , 646-665. https://doi.org/http://dx.doi.org/10.1016/j.jclepro.2016.08.059

Booth, A. T., Choudhary, R., \& Spiegelhalter, D. J. (2012). Handling uncertainty in housing stock models. Building and Environment, 48 , 35-47. https://doi.org/http://dx.doi.org/10.1016/j.buildenv.2011.08.016

Bustamante, W., Cepeda, R., Martínez, P., Santa María, H. (2009). Eficiencia energética en la vivienda social, un desafío posible, en: Camino al Bicentenario, Propuestas para Chile, Santiago. Retrieved from http://politicaspublicas.uc.cl/wp-content/uploads/2015/02/eficienciaenergetica-en-vivienda-social-un-desafio-posible.pdf

Castillo, V. F., Universidad de Chile., Universidad Técnica Federico Santa Maria (Chile), \& Fundación Chile. (2004). Bienestar Habitacional: Guía de diseño para un hábitat residencial sustentable. Santiago, Chile: Universidad de Chile, Instituto de la Vivienda.

Cerezo, C., Sokol J., Reinhart C., Al-Mumin A. (2015). Three Methods for Characterizing Building Archetypes in Urban Energy Simulation. A Case Study in Kuwait City. Proceedings of BS2015: 14th Conference of International Building Performance Simulation Association, Hyderabad, India.

D’Alençon, R., Justiniano, C., Márquez, F., \& Valderrama, C. (2008). Parámetros y estándares de habitabilidad: calidad en la vivienda, el entorno inmediato y el conjunto habitacional. Camino Al Bicentenario - Propuestas Para Chile, (April), 271-304. Retrieved from http://politicaspublicas.uc.cl/wp-content/uploads/2015/02/parametros-y-estandares-de-habitabilidad.pdf

Dineen, D. 2014. Bottom-up modelling of energy demand and technical energy savings potential in the Irish residential sector. PhD Thesis, University College Cork. Cork, Ireland.

Dineen, D., \& Ó Gallachóir, B. P. (2011). Modelling the impacts of building regulations and a property bubble on residential space and water heating. Energy and Buildings, 43(1), 166-178. https://doi.org/10.1016/j.enbuild.2010.09.004

Dyrbol, S. Thomsen, K. E. \& Alnaek, T. (2010).- European Directive on the Energy Performance of Buildings Energy policies in Europe Example of best practices, 2012 ACEEE Summer Study on energy Efficiency in Buildings. pp. 126-140.

Famuyibo, A. A., Duffy, A., \& Strachan, P. (2012). Developing archetypes for domestic dwellings-An Irish case study. Energy and Buildings, 50, 150157. https://doi.org/http://dx.doi.org/10.1016/j.enbuild.2012.03.033

Fumo, N. (2014). A review on the basics of building energy estimation. Renewable and Sustainable Energy Reviews, 31, 53-60. https://doi.org/10.1016/j.rser.2013.11.040 
Foucquier, A., Robert, S., Suard, F., Stéphan, L., \& Jay, A. (2013). State of the art in building modelling and energy performances prediction: A review. Renewable and Sustainable Energy Reviews, 23, 272-288. https://doi.org/10.1016/j.rser.2013.03.004

García-Pérez, S., Sierra-Pérez, J., Boschmonart-Rives, J., Lladó Morales, G., \& Romero Calix, A. (2017). A characterization and evaluation of urban areas from an energy efficiency approach, using geographic information systems in combination with life cycle assessment methodology. International Journal of Sustainable Development and Planning, 12(2), 294-303. https://doi.org/10.2495/SDP-V12-N2-294-303

Ghiassi, N., \& Mahdavi, A. (2017). Reductive bottom-up urban energy computing supported by multivariate cluster analysis. Energy and Buildings, 144, 372-386. https://doi.org/https://doi.org/10.1016/j.enbuild.2017.03.004

Girao, J., Olmedo, A., \& Ferrer, E. (2008). El Artículo de Revisión. Revista Iberoamericana de Enfermería Comunitaria, 6(1), 1-25. Retrieved from https://www.google.com.ec/url?sa=t\&rct=j\&q=\&esrc=s\&source=web\&cd=1\&cad=rja\&uact=8\&ved=0ahUKEwjs9dvtht7TAhWLMyYKHXfID48QF gggMAA\&url=http\%3A\%2F\%2Fwww.uv.es\%2Fjoguigo\%2Fvalencia\%2FRecerca_files\%2Fel_articulo_de_revision.pdf\&usg=AFQjCNFTirzJDBk94JF R49tKA14t4e

Hereen, N., Jakob, M., Martius, G., Gross, N., \& Walbaum, H. (2013). A component based bottom up building stock model for comprehensive environmental impact assessment and target control. Renewable and Sustainable Energy Reviews, 20, 45-56.

Huang, Y. J., \& Brodrick, J. (2000). A bottom-up engineering estimate of the aggregate heating and cooling loads of the entire US building stock. Building Energy Trends, 10, 135-148.

Instituto Nacional de Estadísticas. (2010). Edificación, Informe anual 2009. Santiago, Chile. Retrieved from http://historico.ine.cl/canales/menu/publicaciones/calendario_de_publicaciones/pdf/131210/edi_09131211.pdf

Instituto Nacional de Normalización. (2008). Arquitectura y construcción - Zonificación climático habitacional en Chile y recomendaciones para el diseño arquitectónico. (NCh1079: Of 2008). Santiago, Chile.

Jermyn, D., \& Richman, R. (2016). A process for developing deep energy retrofit strategies for single-family housing typologies: Three Toronto case studies. Energy and Buildings, 116, 522-534. https://doi.org/10.1016/j.enbuild.2016.01.022

Jones, P. J., Lannon, S., \& Williams, J. (2001). Modeling building energy use at urban scale. Proceedings of the Seventh International IBPSA Conference, Rio de Janeiro, Brazil, August 13-15, 2001 (pp. 175-180). Retrieved from http://www.ibpsa.org/proceedings/BS2001/BS01_0175_180.pdf

Karolija, I., Marjanovic-Halburd, L., Zhang, Y., \& Hanby, V. (2013). UK Office buildings archetypal model as methodological approach in development of regression models for predicting building energy consumption from heating and cooling demand. Energy and Buildings, 60, 152.162

Kavgic, M., Mavrogianni, A., Mumovic, D., Summerfield, A., Stevanovic, Z., \& Djurovic-Petrovic, M. (2010). A review of bottom-up building stock models for energy consumption in the residential sector. Building and Environment, 45(7), 1683-1697. https://doi.org/http://dx.doi.org/10.1016/j.buildenv.2010.01.021

Li, C. (2014). Home energy consumption estimation by end use and energy efficiency upgrade recommendations. Duke University. North Carolina, Unite States of $\quad$ America. from https://dukespace.lib.duke.edu/dspace/bitstream/handle/10161/8500/Final\%20report\%20by\%20Chao\%20Li.pdf;sequence=1

Madeira, C., \& Haunstrup, T. (2016). Cluster analysis of residential heat load profiles and the role of technical and household characteristics. Energy and Buildings, 125, 171-180. https://doi.org/http://dx.doi.org/10.1016/j.enbuild.2016.04.079

Manioglu, G., \& Yilmaz, Z. (2006). Economic evaluation of the building envelope and operation period of heating system in terms of thermal comfort. Energy and Buildings, 38(3), 266-272).

Marshall, E., Steinberger, J., Dupont, V., \& Foxon, T. (2016). Combining energy efficiency measure approaches and occupancy patterns in building modelling in the UK residential context. Energy and Buildings, 111, 98-108.

Martínez, P. (2006). Evaluación de la humedad por condensación dentro de viviendas sociales. Revista INVI, 20(55), 154-165.

Martinsson, F., Krook-Riekkola, A., Lindblom, J., \& Wrake, M. (2014). Modelling the Swedish residential and service sector in TIMES: a feasibility study.

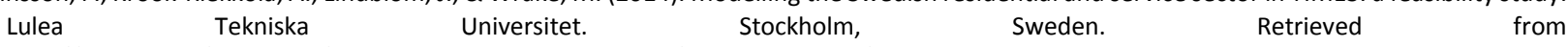
http://www.ivl.se/download/18.343dc99d14e8bb0f58b76b1/1454339652523/B2191.pdf

Mavrogianni, A., Wilkinson, P., Davies, M., Biddulph, P., \& Oikonomou, E. (2012). Building characteristics as determinants of propensity to high indoor summer temperatures in London dwellings. Building and Environment, 55, 117-130. https://doi.org/http://dx.doi.org/10.1016/j.buildenv.2011.12.003

Medina, G. (2011). Bottom-up characterization of the Spanish building stock - Archetype buildings and energy demand. Chalmers University of Technology. Göteborg, Sweden. Retrieved from http://publications.lib.chalmers.se/records/fulltext/164499.pdf

Minfang, T. (2002). Solar control for buildings. Building and Enviroment, 37(7), 659-664.

Ministerio de Energía Gobierno de Chile. (2017). Balance Nacional de Energía 2015. (1a. ed.), Santiago de Chile. Retrieved from http://dataset.cne.cl/Energia_Abierta/Reportes/Minenergia/Reporte\%20BNE\%202015.pdf

MINVU. (2013). ¿Qué es la Calificiación Energética de Viviendas?. Retrieved from http://www.calificacionenergetica.cl/

Mitchell, G. (2005). Urban development, form and energy use in buildings: a review for the solutions project. SOLUTIONS working paper, August 2005. Draft information paper for the EPSRC SUE SOLUTIONS consortium, August 2005. Ver 1.1. Retrieved from http://citeseerx.ist.psu.edu/viewdoc/download;jsessionid=10FDD4F665C48B795AB3E19003F071DA?doi=10.1.1.120.5763\&rep=rep1\&type=pd

Montes, M., \& Moreno, R. (2016). La eficiencia energética en la industria española y las energías renovables. Economía Industrial, 357, $143-163$. 
Müller, E. (2002). E. Müller. Manual de diseño para viviendas con climatización pasiva. Building Research Institute. University of Kassel. Kassel, Germany.

Muratori, M., Roberts, M. C., Sioshansi, R., Marano, V., \& Rizzoni, G. (2013). A highly resolved modeling technique to simulate residential power demand. Applied Energy, 107, 465-473. https://doi.org/10.1016/j.apenergy.2013.02.057

Muringathuparambil, R. J., Musango, J. K., Brent, A. C., \& Currie, P. (2017). Developing building typologies to examine energy efficiency in representative low cost buildings in Cape Town townships. Sustainable Cities and Society, 33, 1-17. https://doi.org/http://dx.doi.org/10.1016/j.scs.2017.05.011

Mutani, G., Delmastro, C., Gargiulo, M., \& Corgnati, S. P. (2016). Characterization of Building Thermal Energy Consumption at the Urban Scale. Energy Procedia, 101, 384-391. https://doi.org/http://dx.doi.org/10.1016/j.egypro.2016.11.049

Ossio, F. (2015). Influence de la qualité des processus de construction dans la performance thermique des logements chiliens. PhD Thesis, Université Catholique de Louvain. Louvain, Belgium.

Österbring, M. (2016). Spatial analysis of urban housing stock. Chalmers University. Göteborg, Sweden. Retrieved from http://publications.lib.chalmers.se/records/fulltext/235187/235187.pdf

Österbring, M., Mata, É., Thuvander, L., Mangold, M., Johnsson, F., \& Wallbaum, H. (2016). A differentiated description of building-stocks for a georeferenced urban bottom-up building-stock model. Energy and Buildings, 120, 78-84. https://doi.org/http://dx.doi.org/10.1016/j.enbuild.2016.03.060

Pacheco, R. (2014). Evaluación y Propuesta de Modelo para el Cálculo de la Demanda Energética en Edificios Residenciales a Partir del Estudio de la Altura y la Integración de Sistemas de Energía Fotovoltaica. PhD Thesis, Universidad de Granada. Granada, Spain. Retrieved from https://dialnet.unirioja.es/servlet/tesis?codigo=57843

Pérez-Lombard, L., Ortiz, J., \& Pout, C. (2008). A review on buildings energy consumption information. Energy and Buildings, 40(3), 394-398. https://doi.org/10.1016/j.enbuild.2007.03.007

Pittam, J., O'Sullivan, P., \& O'Sullivan, O. (2014). Stock aggregation model and virtual archetype for large scale retro-fit modelling of local authority housing in Ireland. Energy Procedia, 62, 704-713. https://doi.org/10.1016/j.egypro.2014.12.434

Raslan, R., \& Mavrogianni, A. (2013). Developing a national stock model to support building energy efficiency research and policy in Egypt. Building Simulation Cairo. Retrieved from http://discovery.ucl.ac.uk/1397102/

Reinhart, C. F., \& Cerezo Davila, C. (2016). Urban building energy modeling - A review of a nascent field. Building and Environment, 97, $196-202$. https://doi.org/10.1016/j.buildenv.2015.12.001

Rojo, C. (2016). Ajustement d'un modéle de calcul en intégrant des paramétres ralatifs aux caracterisques et á l'utilisation efficance des systémes de chaunffage et de ventilation). PhD Thesis, Université Catholique de Louvain. Louvain, Belgium.

Sarmiento, P., \& Hormazábal, N. (2003). Habitabilidad térmica en las viviendas básicas de la zona central de Chile, a la luz de los resultados preliminares del proyecto FONDEF D00I1039. Revista INVI, 18(46), 23 a 32.

Shimoda, Y., Fujii, T., Morikawa, T., \& Mizuno, M. (2004). Residential end-use energy simulation at city scale. Building and Environment, 39(8), 959967. https://doi.org/10.1016/j.buildenv.2004.01.020

Sokol, J. (2015). Deriving archetype templates for urban building energy models based on measured monthly energy use. Massachusetts Institute of Technology. Retrieved from http://hdl.handle.net/1721.1/100355

Sokol, J., Cerezo Davila, C., \& Reinhart, C. F. (2017). Validation of a Bayesian-based method for defining residential archetypes in urban building energy models. Energy and Buildings, 134, 11-24. https://doi.org/10.1016/j.enbuild.2016.10.050

Swan, L. G., \& Ugursal, V. I. (2009). Modeling of end-use energy consumption in the residential sector: A review of modeling techniques. Renewable and Sustainable Energy Reviews, 13(8), 1819-1835. https://doi.org/10.1016/j.rser.2008.09.033

Tornay, N., Schoetter, R., Bonhomme, M., Faraut, S., \& Masson, V. (2017). GENIUS: A methodology to define a detailed description of buildings for urban climate and building energy consumption simulations. Urban Climate, 20 , $75-93$. https://doi.org/http://dx.doi.org/10.1016/j.uclim.2017.03.002

Wilson, E., Christensen, C., Horowitz, S., \& Horsey, H. (2016). A high-granularity approach to modeling energy consumption and savings potential in the U.S. residential building stock. In Proceedings of SimBuild (Vol. 6). Retrieved from http://ibpsausa.org/index.php/ibpusa/article/view/385/371

Yao, R., \& Steemers, K. (2005). A method of formulating energy load profile for domestic buildings in the UK. Energy and Buildings, 37(6), 663-671. https://doi.org/10.1016/j.enbuild.2004.09.007 